\title{
Visual Rhetoric of the Truth in the Dreyfus Affair: A Semiotic Approach
}

\author{
Nathalie Hauksson-Tresch ${ }^{1}$ (D)
}

Published online: 13 March 2019

(c) The Author(s) 2019

\begin{abstract}
At the turn of the twentieth century, French society was shaken by a scandal that affected it at many levels to varying degrees and that is still considered as a symbol of injustice, miscarriage of justice and antisemitism. The Dreyfus Affair started in 1894 when an artillery officer of Jewish descent was convicted and sentenced to life imprisonment for communicating military secrets to the German embassy in Paris. Only years later was Alfred Dreyfus exonerated and rehabilitated, due mainly to the role of the media and the famous article by the novelist Emile Zola, "J'accuse". The press, in general, played a fundamental role in the narration of the event and in the complex chemistry that led a confidential case of espionage to become a broad public debate, exemplifying the constant struggle against prejudice and irrational impulses that implies democracy. From the impressive volume of publications, I selected two drawings issued when the truth about captain Dreyfus's innocence began emerging. One is by Félix Vallotton, "That's why she was not coming out!", the other by Gustave-Henri Jossot, "She was too naked", and they both give an interpretation of the truth and of the reasons why it - the truth-came out so late. The semiotic approach of the drawings and of Zola's pamphlet in terms of visual message leads us to distinguish three aspects. The first is iconic and consists of establishing the links between a signifier, a signified and a referent in order to recognize the immediate message but also the connoted signification; the second is linguistic and consists of the captions; and the third is plastic, focusing on size, colors and shapes. These analyzes of the mode in which visual artefacts produce meaning and provoke an interpretative process are made in terms of rhetoric insofar as rhetoric is considered, not only in terms of figures of speech, but as a method of persuasion and argumentation.
\end{abstract}

Keywords Dreyfus affair · Truth $\cdot$ Visual message $\cdot$ Iconic $\cdot$ Linguistic $\cdot$ Plastic message $\cdot$ Rhetoric $\cdot$ Satirical

Nathalie Hauksson-Tresch

nhaukssontresch@gmail.com

1 Dalarna University, Falun, Sweden 
Gustave-Henry Jossot, "Elle était trop nue"
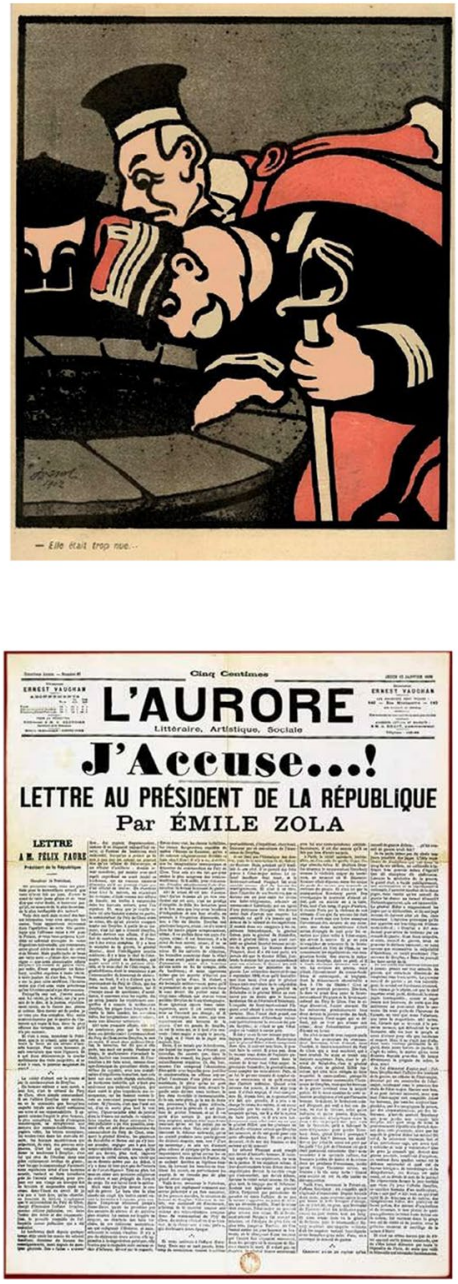

Félix Vallotton, "Voilà pourquoi elle ne sortait pas"

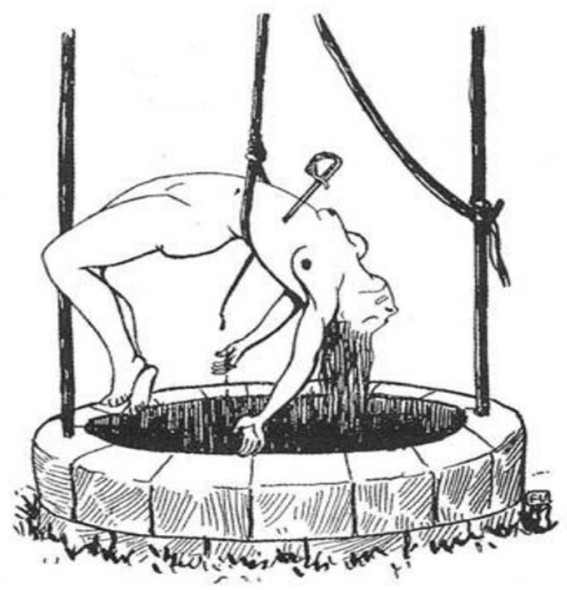

\section{Introduction}

The purpose of this article is to shed light on the mechanisms by which a visual sign develops and transmits messages, how they are apprehended, according to what semiotic mechanisms they present. The message in question is the one of truth and its counterpart, the denunciation of deceit, in a context marked by an impressive accumulation of lies. Defining truth usually falls under the discipline of philosophy, can be surprisingly challenging, and since it is not my aim, I will satisfy myself with a common definition of truth—that being "in accordance with fact or reality" [25]. 
The historical background of this reality is the Dreyfus Affair, which occurred in France at the end of the nineteenth century and which is still considered today to be a symbol of miscarriage of justice and anti-Semitism [34].

An accusation of treason was made in 1894 against Alfred Dreyfus, a Jewish captain of the French army. He was suspected of delivering secret reports to the German Embassy during a time when France had barely started to recover from its defeat against Prussia in 1871, and social tensions were growing [4]. The captain was sentenced to life in a penal colony in December 1894 and publicly degraded in 1895 , although no proof could ever be found against him. The evidence pointed on the contrary to Ferdinand Esterhazy, a military officer and spy of the German empire. Whatever the case, Esterhazy was discreetly dismissed by the army and sent away from France until later on, Mathieu Dreyfus, the convict's brother, made his name public and forced the authorities into action. As a result, Esterhazy was brought before a war council in 1898, yet was acquitted, confirming thus the double scandal of an innocent man being sentenced and a guilty man being discharged. Although everything seemed lost for the Dreyfusards at the time, and the Affair seemed buried forever, they did not count on the intervention of the famous writer Emile Zola, who shouted with all his might: "J'accuse !": "I accuse!" and predicted that "truth is in progress, and nothing will stop it" [35]. The article was published January 13, 1898 in the newspaper L'Aurore and with its emphatic, dramatic and polemic style, it exploded in the public discourse and reignited a problem that authorities had believed they'd handled. It had such an impact that it started a process that ended with the president of the French republic pardoning Dreyfus before he was finally rehabilitated in 1906 by the Supreme Court [26].

Anyone interested in the narration of the Affair will be surprised by the mass of documents at their disposal [10]. Indeed, the case has given the opportunity to countless people to express themselves, thus giving birth to the most vast and varied corpus: articles, poems, novels, songs, drawings, paintings, later on films and there is even a board game related to it. A profusion of visual artefacts in favor of the convicted met an even greater amount of productions were anti-Dreyfusards exploited the theme of the traitor and anti-Semitism [3]. The reference to the betrayal of Judas becoming one of the constants of the hateful vein of satirists [31,32].

I singled out two drawings that were published in satirical newspapers close to anarchist movements of the time and that highlight a moment when the truth finally emerged, as well as Zola's article "J'Accuse", considered alike and foremost as a visual message. The first drawing is by Félix Vallotton and served as the cover illustration on May 14, 1899 for Le Cri de Paris. Its caption states "So that's why she was not coming out" ("Voilà donc pourquoi elle ne sortait pas"). The second one is by Gustave-Henry Jossot and was published in 1903 in L'Assiette au beurre with the caption "She was too naked" ("Elle était trop nue") [18]. These two drawings are especially rich and susceptible to extended semiotic analysis.

Visual representation is a matter of debate and philosophical reflections since the antiquity, and the famous opposition between Plato and Aristotle. Art of imitation, fabrication, illusion, it deceives for the one, educates for the other. Our modern world, where images are omnipresent, illustrates these two aspects arguably better than it ever has, and even more when pictures are intended to persuade specific 
audiences, rather than made just for aesthetic pleasure. In a semiotic sense, an image is, first of all, a sign constituting a language and "by language [I] mean any system of communication which uses signs arranged in a particular way" [20: 34], the term language being here used in the widest possible way, englobing signs that are not usually considered "language-like" as they do not have syntax.

An image represents something, which is to say that it is not the thing itself; its function is, therefore, to evoke, to signify something other than itself, often through the use of the process of resemblance [14: 35].

Semiotic theory takes simultaneously into account non-iconic and iconic signs, namely analogical signs. The concept of "icon" comes, of course, from pragmatism and was developed by Pierce. We know, since Saussure and Pierce, that even though signs can be many and varied, they all have a common structure based on a tri-polar relationship linking a signifier to a referent and a signified (Pierce names these functions, with relatively small semantic variations, "representatem" or sign, object, and interpretant) [16]. To distinguish the specificity of each type of sign, Pierce proposes a classification where the signs are organized depending on the type of relationship existing between the signifier (the perceptible aspect of the sign) and the referent (the represented object). Pierce distinguishes three main types of signs calling them "index", "symbol" and "icon". To be brief, let us not forget that the icon maintains a relationship of analogy with its referent: what it represents is like the object, as in the case of a figurative painting. The symbol is a type of sign that has a conventional relationship with its referent. As for the index, it displays evidence of what is being represented, for example smoke to indicate a fire. Nevertheless, no sign is univocal; most have only dominant characteristics and are fundamentally heterogeneous. These dominant characteristics express themselves through messages that all images have in common, as shown by the French semiologist Martine Joly: an image coordinates different categories of signs, some of them iconic, others plastic-such as colors, shapes, internal composition, texture - and most of the time also linguistic signs, verbal language. In Joly's conception, these verbal signs escort and complete the pictorial artefact [14: 34]. Martine Joly proposes an analytical method that consists of approaching the image from the angle of meaning and not that of emotion, or aesthetic pleasure, for example [15]. It is her lead I choose to follow when discussing my small corpus, in addition to the method exposed by Roland Barthes when he interpreted an advertising image in terms of rhetoric in 1964 [1]. Barthes aimed to find out if the image contained signs and if so, which ones. He assumed that the signs to be found had the same structure as that of the linguistic sign, proposed by Saussure. Seeing that he was analyzing an advertisement (in this case for pasta by Panzani, a brand name) he, of course, knew already what the message was, so he thought out the signifiers and associated them with signified and referents. At the end of this process, he was able to identify what he called "full signs" that contributed to the construction of the global and implicit meaning of the image.

The main originality of the Barthian approach is to the study the visual artefact in terms of rhetoric. The idea of a general rhetoric, already suggested by Freud and Lacan, was really formulated by Roland Barthes when he stated that it "is even probable that there exists a single rhetorical form, common for instance to dream, literature, and image" [1: 161]. 
For Barthes, the different materials of the image are first linguistic (text accompanying the image) and further iconic. The iconic message is decomposed into uncoded and coded iconic, the latter being made up of different signs. Beyond the literal or denoted message, highlighted by the description, there is a symbolic or connoted one related to a pre-existing knowledge shared by the receiver (the public) and the emitter (the creator). These designations are fundamental and will be included in the wider categories by which I construct my article. I will first consider the iconic message of my corpus; I will then turn to the linguistic message and finally to the plastic message, which is studied separately as an independent system of signs. Of course, isolating these messages is somewhat artificial in so far as every image-graphic or not-is always complicated, and the eye perceives none of the variables independently. It is the interaction of these three signs that produces meaning, meaning that a systematic decryption should allow us to better understand.

\section{The Iconic Message}

Describing the iconic message amounts first of all to a narration of what we see, before analyzing what it means. Just as with the ancient tradition of rhetoric, an iconic message involves two levels of language, one literal and the other more figurative, the figure being an operation that takes the receiver from one level of language to another. What is said figuratively could have been said in a more direct, more straightforward fashion and as a matter of fact, it might be through the transposition of rhetorical figures acknowledged for many centuries that the most original and audacious ideas appear, even if the pictorial artists are not necessarily fully aware of a system they intuitively use [7: 91]. This is probably linked to the notion of quality since rhetoric is also the repertoire of the different ways in which one can be "original" [24: 262]. Of course, this transition from one level to another is realized, symmetrically, at two different moments: at the moment of creation (the emitter of the sign starting from a simple proposition to transform it by means of a rhetorical operation) and at the moment of reception (the receiver restoring the proposal to its clarity) [7: 70-71].

Paradoxically, by merely trying to describe what is seen in the two drawings the receiver is inexorably brought to question what he or she does not see, as both artefacts have a visible and an invisible iconic aspect.

\subsection{The Visible}

Gustave-Henry Jossot's drawing is made of iconic motifs which seem easy to read until the analysis proceeds further. The components are three male characters and a stone circular structure. We note that the three characters, who lean forward and look with intense focus into the construction, although different, have a similar type of clothing: all wear rich headdresses and costumes complete with significant details. Furthermore, the figure in the foreground holds a sword. The identification of the characters requires, however, an interpretation based on sociocultural knowledge 
to recognize a soldier in the foreground, then a judge, then a clergyman, all standing around a well. As a matter of fact, "global responses to a visual field are the result not of an extensive sensorial perception, but rather of a process of interpretation which extrapolates to the totality the meanings extracted from major or minor details, in liaison with mnemonic visual images" [30: 10]. Jossot may well have been inspired by real people in this example, but the drawing offers only generic figures, able to evoke any judges, military officers and priests. A drawing that allows us to recognize a soldier, a judge and a priest is a solid sign according to Roland Barthes's interpretation: a signifier connected to a signified, connected to a referent. Nevertheless, this full sign continues its dynamic by becoming the signifier of a second signified and referent: the military force, the department of justice and the church. In terms of rhetoric, we can say that these three figures entertain a metonymic relationship with their referents in so far as they all wear the uniforms of their function. The soldier represents the military that conspired to have Dreyfus condemned and Esterhazy acquitted, the judge represents the judiciary that actually sentenced Dreyfus without proof and let Esterhazy go free, and, finally, the priest represents the church, which in turn probably represents the anti-Semitic aspect of the case. Dreyfus was also condemned because he was Jewish, the ideal culprit indeed. As for the presence of three personages instead of merely one, this can be perceived to be a rhetorical figure of accumulation, often used as a form of invective that is notably adequate in a political cartoon like this one. We are faced with the presentation of characters constituting a closed paradigm. They participate in an event, and the artist seems to have visually grouped them so that they can be understood as part of a single system.

\subsection{The Invisible}

Beside the visible, there is the invisible, something we, as viewers, do not see. Indeed, the figures scrutinize the bottom of the well, thus stimulating our imagination. We can assume that the emitter, the artist, expects us to know what his characters are observing. This is something primarily recognized by the founders of the aesthetics of the reception, Jauss and Iser, for whom the literary work stimulates the reading activity as much by what it does not say as by what it does say- the difference being that an icon does not "say" but shows or... does not show. Considered in the materiality of its arrangement, the image would thus include blanks, voids, in short, the implicit that needs to be activated by the viewer. Umberto Eco, in Lector in fabula, analyzed the phenomenon of reception also in terms of interpretative cooperation between the text and its reader.

A text is a web of white spaces, gaps to fill, and the one who issued it predicted that they would be filled and he left them blank for two reasons. Firstly, because a text is a lazy (or economic) mechanism that lives on the added value of meaning introduced by the recipient [...] Then because, as it passes from a didactic function to an aesthetic function, a text wants to leave the interpretive initiative with the reader, even if in general, it wishes to be interpreted with 
a sufficient margin of univocity. A text wants someone to help it work $^{1}$ [8: 63-64].

And just as by "lector", Eco does not mean the empirical public, so we will imagine here a model viewer, who is able to cooperate with the actualization.

The French proverb that affirms that the truth is at the bottom of the well or that the truth comes out of the well allows us to imagine what the characters scrutinize so intensely. In the strict sense, reading this drawing is only possible in languages that use the image of the well. In English-speaking cultures, many would probably say "the cat is out of the bag" even if the image of the well is of course also present, with its implication of depth or deep water. More generally speaking, it is always the knowledge common to all members of the same cultural community that determines understanding.

The invisible is pointed out to the viewer by way of the positions of the characters. Their eyes, the hand of the soldier who enters the well, the place left free in the foreground-everything invites the eye to enter the well and stare at the invisible. The position of the bodies has in fact a perlocutionary function, inviting us to do something. The alignment of the heads and their inclination, the way of organizing them according to a semi-circle, would indicate in advance our place, remained free at the front. The close-up invites us indeed to lean over the ledge and thus persuades us of the validity of the statement.

Truth is one element we do not see in Jossot's drawing but it is also far from the only one. Indeed, it is rather remarkable that although the military, the judiciary and the church are represented, we do not see any representative of the executive nor legislative powers. The presence or absence of an element is a choice that must be taken into consideration as much as possible. From a methodological point of view, we can retain the principle of substitution as a means of distinguishing the various components of the image, thus applying to the visual language one of the fundamental laws of the verbal language, that of axiality along the paradigmatic axis (vertical line, choice of words) [14: 50]. So, the fact that we do see a soldier, a judge and a priest, and that we do not see a political figure, are far from neutral factors and may point to the way the artist evaluates accountability in the Dreyfus Affair.

To shed light on this choice, we can turn to Zola's article, which has the rhetorical quality of a judicial discourse, having in that case and in an iconic sense, the real judicial discourse as a referent. Classically the text begins with an exordium, associating the interpellation of the president of the republic, the exaggerated praise of his past actions, a warning against the repercussions of the Affair on his image and that of France and the announcement of a duty to assume: "The truth, I will say it, because, I promised to say it". The function of the exordium is to attract the benevolence of the audience, to expose the subject of the speech and to indicate the essential articulations. The narrative of the facts and their analysis intertwine on two successive scopes, those of the two cases: the Dreyfus Affair and the Esterhazy Affair, each of which offers a triadic model of Ciceronian discourses: the narration, the

\footnotetext{
1 My translation.
} 
refutation of acts and of adverse views, and the confirmation: the reasoned reaffirmation of the initial certainty: Dreyfus is innocent, his accusers have lied, Esterhazy is guilty, his acquittal is a crime. Zola's "J'Accuse" ends with a peroration which synthesizes the argument, names the culprits, and appeals to the feelings of the audience, especially through the use of pathos. The part that is the most oratorical and daring in the article is at the end: the scansion of the indictments and the challenge to power: "So may one dare bring me to criminal court, and may the investigation take place in broad daylight! I am waiting." It is an uncompromising and dense construction, an aesthetically calculated form with not only a logical structure but also a movement, a rhythm, with parallelisms, symmetries, amplifications and great lyrical moments, but it does not include the disparaging of the executive and legislative powers as such.

\subsection{The Invisible Made Visible}

In Felix Vallotton's drawing, we see a naked woman, pierced by a sword hanging on a rope over a well. The drawing illustrated an article defending Dreyfus which can indicate that by virtue of it, we are presented with the real appearance of Truth. What we do not see in Jossot's drawing is visible in Vallotton's.

Vallotton chooses the allegorical mode to evoke Truth, which is a way to visualize the invisible. In Western societies, it is often a woman's body that has served as a visual support for the allegory of values and virtues that have no other existence than in our minds.

Whereas allegories were mostly rejected in paintings by the middle of the nineteenth century, the use of allegorical figures continued in cartoons and drawings without any questioning, until today. Marianne, for example, still embodies transparently the French republic. If these illustrations are understood by others than those who make them, it is once more because there is a minimum of sociocultural convention between them-in other words, it is due to the fact that a large part of their meaning comes from their dimension as a shared symbol, according to the definition by Pierce.

In this version, Truth is naked, as it usually is, and is left hanging from the rope above the well, a sword through her chest. As we know, it is mostly in totally naked form that Truth is known to us in iconography, whereas Justice, for example, according to encoded iconological tradition, is clothed, together with Liberty, who occasionally carries a scepter. Truth, on the other hand, will have no other attribute than her complete nudity.

The image is quite forceful. We recognize a denunciation of the role played by the military given the sword, a metonymic substitution. The sword is very similar to the one used by French officers and to the one we see in Jossot's drawing. The importance of the military sword might equally remind the receiver of Dreyfus's sword, which was broken in a particularly humiliating ceremony on January 5, 1895, in the courtyard of the Military School. The ceremony was illustrated on the front page of Le Petit Journal with the caption "The Traitor" and remains strongly fixed in the collective memory [19]. 
We see blood dripping from the sword as we are given a hyperbolic and dramatic representation of the murdered Truth. Obviously, the manifestations of Truth can be bloody when she comes out of its well. We are faced with a double meaning and paradox: the truth is out in the open, but the truth is dead, but the truth cannot die because it is out in the open...

It is very remarkable that the drawing is almost incomplete. The receiver does not know who pulled Truth out of the well, and she is floating almost supernaturally, the rope holding her is not even stretched by her weight, presenting an almost eerie feeling. This lightness is a transgression close to a visual ellipse, which consists of the removal of certain elements of the image: objects, characters, etc. The rendition is perceived as incomplete and can nearly be interpreted as an illustration of a fantastic scene. Interpretation of an ellipse is quite complex as it is not only a matter of removing an element but also of bringing the reader to perceive this absence and to reconstitute the missing element: here the forces united to reveal the truth. We can, however, interpret this artifice as a willingness to emphasize the main message: it is irrelevant who pulled Truth out of the well-she is there, naked, entirely exposed for everyone to contemplate.

To conclude this passage devoted to the iconic message, I must point out that the Dreyfus Affair is only subtly summoned up by Jossot and Vallotton. Only by iconographic connotation can the receiver contextualize the drawings, as the allegory of Truth was extensively used in relation to this particular miscarriage of justice. Many readers must indeed have had in mind the painting by Edouard Debat-Ponsan offered to Emile Zola as recognition of his commitment and entitled "Nec mergitur" or "The Truth Coming Out of the Well". It portrays a triumphant Truth coming out of a well, brandishing a mirror while two characters, a priest and a masked man, try to hold her back [33].

\section{The Linguistic Message}

As far as the linguistic message is concerned, Barthes distinguishes the various supports and analyzes the rhetoric and its articulation with the visual message. The opposition image/language appears to be a false opposition, while language not only participates in the construction of the visual text but relays it, even completes it, in a reflective and creative circularity. It is mostly agreed that the linguistic message, when present, is decisive in the interpretation and channeling of the visual communication which otherwise could produce various meanings, in accordance with its often polysemic nature.

Barthes isolated the linguistic messages within the visual communication to study the type of relationship they maintain and the way the words direct the reading. For him there are two main possibilities: either the text has an anchoring function, or it acts as a relay. The anchorage has the task of designating "the good level of reading", in putting a stop to a "floating chain of meanings" that is generated by the necessary polysemy of the image [1]. It tells the reader what to privilege among the different interpretations that can be generated by the image alone. The relay is useful, 
for its part, when the linguistic message aims to replace the expressive deficiencies of the visual. It is a way of taking over.

The two functions can be deduced from a close analysis of the captions. Both legends have the personal pronoun "she" in common. The caption in Jossot's drawing is "She was too naked"; the one under Vallotton's drawing takes the form of an exclamation: "So that's why she was not coming out!". The only way to explain what the personal pronoun "she" refers to is through a mediation between the two signs: linguistics and iconic. This is noteworthy since the text often has a "repressive" value [1], imposing a reading upon the graphic. Contrariwise here, to find out if the "she" of the caption refers to Truth, as I stated earlier, we must question the link established between the icon and the verbal messages, especially in Jossot's drawing, considering that the anchoring here takes the form of a rhetorical "suspension" [1] in so far as the reader does not get to see but has to imagine who or what is hidden behind the personal pronoun. To stimulate the imagination of the receiver, the artist uses what in terms of rhetoric is called a shifter in the sense used by Roman Jakobson: «a term whose meaning cannot be determined without referring to the message that is being communicated between a sender and a receiver" [12: 132].

We can consider that the attitude of the characters works here as a "shifter". Indeed, the bodies are leaning forward, and the eyes are actually pointing down. Their essential function is to direct our eyes, as receivers, to the truth. It is also inviting us to ask the question of the relation between the visible and the invisible. And because, in fact, the characters point out the truth not to their companions in the icon but instead to us, on the outside, it is a real communicative action: between the space of representation and the real space where we are. We can furthermore see that the anchorage is made particularly strong in Jossot's drawing by the presence of a dash, a sign denoting a speaker in a dialogue, as though the three characters had been discussing the enigma of the Dreyfus Affair and as though one of them had concluded that the truth is too naked to be seen in public. It can, of course, refer to the truth about the innocence of Dreyfus but it can also refer to the truth about the three characters. Wells are usually very deep but can have a reflective surface if the bottom water level is visible. If that is the case, are maybe the three characters seeing their own reflection? Is something about their own intentions being caught out reflected in their own faces seen in the water? Is their guilty conscience looking back at them?

To know who says the words, it would be necessary to see the lips of the characters. However, the mouth of two we cannot see, and the third mouth-that of the judge - although clearly visible is closed, contracted, expressing disgust or scorn.

In Vallotton's drawing, the visible leaves no doubt that it is indeed Truth coming out of the well; nevertheless, we can consider the use of the pronoun "She", instead of naming Truth, as being a way to acknowledge a form of complicity with the reader, with whom the sender shares a common cultural background.

The function of relay is not absent from the captions. Indeed, despite the expressive and communicative richness of a purely visual message, there are things it cannot convey without recourse to the verbal, such as, for example, grammatical timehence the use of the past tense in both captions: She was too naked, She was not coming out. This can be explained by the fact that they were published after the truth had come out as a result of Emile Zola's pamphlet. The artists take us back to 
a time when the nation still widely believed in the culpability of captain Dreyfus. Indeed, the past tense could be explained by the fact that Truth struggled and took so long to come out, and the explanation is to be found in Vallotton's drawing... In the familiar form of an impersonal enunciation, the author gives us to understand why the Dreyfus Affair took so long to be resolved.

Another element to be questioned is the adverb "too" associated with the adjective "naked". In this context, we can assume that it conveys a moral idea, an absence of conformity to the norm. This idea is expressed furthermore by the ellipsis as Truth was too naked to be accepted by the required moral norm. The link between the normative aspect and the social function imposed by the three characters, the military, the judiciary and the clergy, is thus clear: to maintain the moral order. The author plays with the dual level of reading, literal and symbolic: naked truth/naked woman. In so far as the topic is the nakedness of Truth, and the fact that in this particular case we should consider nakedness as a virtue, we ought to note the acerb criticism implied here.

To complete the review of the linguistic message, we can note that it is constructed in the form of a proposition that expresses a judgement in both cases. One or more people speak here and now, and it is the meaning of the indicative mode to mark the presence of those who judge and to emphasize how what is said must correspond to reality.

\section{The Plastic Message}

I chose to consider the plastic message as a full sign and not only as the signifier of the iconic because it allows for a richer rendition of the different dimensions of the visual communication. I study it last, while being aware that it is arbitrary and that in the reality of the perception it is perhaps the plastic message which comes first in this stage of pre-attention mentioned by cognitivists, this fleeting moment when we decide whether to continue looking or not. The plastic aspect of a visual artefact can be compared to the poetic function of a text as described by Roman Jakobson, just as the iconic sign can be linked to the referential function [29, 11:218]. It is composed of different visual variables, one of them being the medium.

\subsection{The Medium}

As an external factor, the medium in which an artefact is published is sometimes not taken into account in a semiotic analysis, but I consider it of importance inasmuch as it determines the grade of visibility. A drawing appearing, for example, on an inside sheet of a newspaper will necessarily have a lower index of iconicity than a cover page [21].

Jossot's drawing was published in 1903 in L'Assiette au beurre, a weekly magazine of about sixteen pages, printed in color and specializing in social caricature. The publication was known for its sympathies towards the anarchist movement and each issue was devoted to a specific theme and headed by a particular artist or group 
of artists. For the first time and in a systematic way, designers were called on, individually or together, to paint small frescoes that were social or political in nature and to draw up an indictment on a specific case [9]. "Elle était trop nue" was first issued at a moment when the innocence of Dreyfus had not yet been officially recognized (it would not be until 1906), but the case was once more the center of mediatic attention after an assassination attempt was made against the captain at the funeral of Emile Zola. It was published in a number entitled "Passementerie", prefaced by Henry Bérenger, writer and journalist [18]. This issue was composed of thirteen full-page drawings opposing the "Passementerie" to the "Truth". Jossot's illustration can be found on page 13 (there were 19 pages). Its hour of fame would, in fact, come much later, when it was used as cover for a book on the Dreyfus affair [23]. When considering the iconic message, I concluded that the three figures in the drawing represent the military, justice, and the church but by widening my approach to the medium, I can take into account the physical context of the publication and draw the conclusion that they are also a symbol of falsehood and dishonesty, or, in other words, "passementerie".

Vallotton's drawing was published on the cover page of Le cri de Paris in May 1899, giving it immediate visibility. The journal, which also promoted anarchist ideas, was composed of 16 pages in black and white and contained mainly texts with drawings. The general tone of the newspaper was resolutely in favor of Dreyfus and against colonialism, and the following message was included in all publications by the same editor: "Le Cri de Paris asks its readers to help it fight the abuses, big and small, which the public has to suffer every day" [5].

This issue was released only a few months after Zola's article appeared on the cover of L'Aurore, a daily newspaper which early on took the side of Dreyfus. At that time the paper was seen as the main voice for the captain's innocence and review of his trial. On the 13th of January 1898 300,000 copies of L'Aurore were bought on the streets of Paris whereas the newspaper usually sold between 20,000 and 30,000 copies.

The other aspects of the plastic message refer to the area named "coloreme" by the semiologist and visual arts theorist Fernande Saint-Martin, which is "the zone of the visual linguistic field correlated to a centration of the eyes. It is constituted by a mass of energetic matter presenting a set of visual variables" [30: 5]. The variables I retained are the frame, the perspective and composition, and the colors.

\subsection{The Frame}

Every visual artefact has obviously physical limits, but not all have a drawn frame. A depicted frame delimits a drawing, isolates it from what surrounds it, creates the "outside of the field" where the receiver is. In a way, the frame, as we see it in Jossot's drawing, also tells us that a visual artefact is only this and in no case the reality of the world. In a way, it can be seen as a container necessary lest the picture be too powerful.

When we consider Vallotton's picture, we are of course surprised by the absence of a frame. Nothing is there to keep the receiver out of the picture, which accentuates 
the violence of the representation. Moreover, the eye is puzzled by the unfinished character of the image as we do not see the top of the well, as if the artist lacked room to draw it. This of course is to trigger the imagination of the viewer, who will construct what is not seen. Moreover, as Martine Joly has shown, the absence of a frame presides over a culturally very marked conception of the picture, which implies, beyond the aesthetic choices, a genuine ethic of the icon. Indeed, by masking the character of representation (that is to say of construction) of the icon, it is given not as a visual statement, an interpretation, but as the world itself [13].

Zola's text has no drawn frame and almost fills the entire page. It is almost as if the limit of the printed words corresponds to the physical limit of the paper. It gives an impression of crowdedness as if the large number of words testifies to the commitment of the author to say everything and hide nothing. The text continues even on to the second page of the journal.

\subsection{The Perspective and Composition}

Jossot's icon shows three half-length figures, strongly compressed. The angle of view, at man's height, communicates an impression of great proximity. The figures take on a monumental aspect. Just as the presence or absence of an element (iconic aspect of the message), the place is a choice that must be taken into consideration as much as possible. Once more, from a methodological point of view, we can apply to the visual language a fundamental law of the verbal language, that of syntagmatic axiality (order of the words). The plastic composition of the drawing (we first see a soldier, then a judge and finally a priest) would make sense: the Dreyfus Affair was at first a military affair, then legal, then religious, the Catholic Church having been repeatedly accused of anti-Semitism. These elements point clearly to the way the artist constructs the chain of responsibility and is confirmed by the sword in the foreground.

The great proximity communicated by Jossot's work is even manifested in Vallotton's drawing with the same angle of view, at eye level. The figure is represented slightly to the left as if to make space on the right for the imaginary character that dragged her out.

As for Emile Zola's article, the words are indicated above all by their typography and their layout in the page. Their reciprocal hierarchy is indicated by the height and thickness of the letters. The visual appeal of the thickness and massiveness of the mark actually causes a first scan of the page. Of course, the words have an immediately understandable meaning, but this meaning is colored, tinged, oriented, even before being perceived, by the plastic aspect of the typography (its orientation, its shape, its color, its texture), in the same way that the plastic choices contribute to the meaning of the visual image. This has been studied by Jacques Bertin in Sémiologie graphique under the name of "retinal variables" [2].

The plastic aspect of Zola's article lies mainly in the title. "J'Accuse" is a scandalous title that stands out for its modernity. The characters chosen by the editorial staff of L'Aurore are letters used usually for printing posters. J'Accuse, with double capital letters on the $\mathrm{J}$ and the $\mathrm{A}$, is a title that can be seen from a distance. 
It is a title for the street, a title to be shouted by the sellers of L'Aurore, almost a title that calls for a fight. At the end of the nineteenth century, the event is undeniably in the street, in the middle of the shouts and reactions of the crowd [22].

There is a contradiction between the length of the article (a lengthy account of the events that, when printed, reaches the dimension of a sixteen-page brochure) and the brevity of its title, which sounds like a whiplash. It is Georges Clemenceau, the editor of the newspaper, who will later become prime minister, who chose the title as Zola had more soberly opted for "Letter to the President of the Republic".

As the linguist Alain Pages has shown, "J'Accuse" is paradoxically a long speech that can be abbreviated in two syllables, a short open vowel followed by a closed vowel. Almost like a clip, an advertisement, a whole speech enclosed in two words, with the threat of the points of suspension and the exclamation mark that follows: figures of interruption and suspense, aposiopesis, to use the language of rhetoric [27].

In addition to the title, it is important to emphasize the conative value of "J'Accuse" since the text adopts the form of an open letter to the President of the Republic, encouraging him to act in the name of truth and justice. This aspect is graphically visible.

Another plastic element that catches the eye is indeed the long list of Zola's accused, rendered manifest by the use of an anaphora graphically accentuated by indentations:

I accuse Major Du Paty de Clam as the diabolic workman of the miscarriage of justice $[. .$.

I accuse General Mercier of being an accomplice [...]

I accuse General Billot of having held in his hands the indisputable evidence of Dreyfus's innocence [...]

I accuse General De Boisdeffre and General Gonse as accomplices of the same crime $[\ldots]$

I accuse General De Pellieux and commander Ravary of performing a rogue investigation $[\ldots]$

I accuse the three handwriting experts, sirs Belhomme, Varinard and Couard, of submitting untrue and fraudulent reports [...]

I accuse the offices of the war of carrying out an abominable press campaign $[\ldots]$

Finally, I accuse the first council of war of violating the law by condemning a defendant with unrevealed evidence, and I accuse the second council of war of covering up this illegality.

The force of the title, the epistolary form and the direct accusation certainly explain the tremendous repercussions of the feature. Such is the danger that others try to minimize it by founding their anti-J'Accuse paper in early February 1898. Responding to Zola's terrible word by the hiss of disdain and a rhetorical litotes: Psst...!, trying to chase all meaning from L'Aurore's title [28, 31]. 


\subsection{The Colors}

Equally meaningful is the color technique used by an artist. In Jossot's case, we notice solid colors that, in addition to directly correlating to their referents in the visible reality, are applied on simplified areas and flat surfaces inspired by the technique of Nabi painters [17]. Michel Dixmier spoke of Jossot's characters and objects as "cut by linear arabesques into unmasked solid flat areas" [6: 3]. Black and white are evidently integrated into Jossot's chromatic universe. The third basic color he uses is red. The saturation of red and black is remarkable, giving them "the maximum level of chromatic intensity" [30: 35]. He mixed them to obtain two sub-tints, a sweet pink and a soft grey, which are also presented in a uniform way and without any asperity, thus reducing the depth.

The brilliance of colors in Jossot's work contrasts with the sobriety of the lines in Vallotton's drawing. While the skin of Jossot's characters is pink, it is totally colorless in Vallotton's representation, based on the opposition of two complementary colors, white and black ${ }^{2}$ [29], which once more accentuates the roughness and violence of the representation.

\section{Conclusion}

The Dreyfus Affair caused a major upheaval in French public life, with innumerable consequences that influenced many aspects of society.

In the wake of the recognition of Dreyfus's innocence, the Republican Regime, which had not yet entirely affirmed its foundations, was strengthened, and the leftwing political parties reinforced their power against supporters of a more authoritarian order. The separation of powers was confirmed, the military lost some of its authority, and its hierarchy underwent a real purge. The separation of church and state was declared by law in 1905, and laicity became a fundamental principle sustained to this day. And last, but not least, the media asserted itself as a very strong counterpower.

Of course, Emile Zola's “J'Accuse" was the cornerstone of the mediatic activity at the time, but other means, more visual, played a part, and the contribution of artists such as Henri Jossot and Felix Vallotton should not be ignored, even if that is difficult to evaluate in terms of influence. Some satirical drawings, such as political cartoons are, after all, known to have had a relevant psychological, emotional, and political impact in history.

Information through image is rendered complex by the possible polysemy it generates. To construct the overall meaning of a visual artefact, the receiver needs to activate different tools and take into consideration various types of signs. These signs have been the object of my modest research. The iconic allows the construction of the chain linking the signifier to the signified, to the referent, thus identifying the denoted message that in turn will give access to the connoted communication.

\footnotetext{
${ }^{2}$ The others are red/green, blue/orange, purple/yellow.
} 
The linguistic message, as well relay as anchorage, appears like a tool helping with this process. However, it is clear that this operation of association is not always successful, and it is the task of the analyst to identify the solicitations at work. This requires a consideration of the context and the purpose of the visual sign. As for the plastic message, its role is to "aesthetize" the representations, paradoxically removing the receiver from the reality that it is supposed to represent, rendering acceptable the spectacle of the world, even in its most difficult aspects. It reminds us that the three objects of my analysis have both a conative function as tools of information and even propaganda as well as an expressive or emotional function as aesthetic creations.

These three dimensions - iconic, linguistic and plastic - allowed us to explore the most well-founded and the most common interpretations without, however, accounting for either the totality or the variety of individual interpretations, which depend on the sociocultural knowledge of the spectator and foremost on his or her horizon of expectation.

Open Access This article is distributed under the terms of the Creative Commons Attribution 4.0 International License (http://creativecommons.org/licenses/by/4.0/), which permits unrestricted use, distribution, and reproduction in any medium, provided you give appropriate credit to the original author(s) and the source, provide a link to the Creative Commons license, and indicate if changes were made.

\section{References}

1. Barthes, R. 1978. Rhetorique of the Image. Translated by Stephen Heath in Roland Barthes Image, Music, Text, New-York, Hill and Wang: 151-163. The original text can be found in Communications 4, 40-51, Available at https://www.persee.fr/doc/comm_0588-8018_1964_num_4_1_1027. Accessed 2 Nov 2018.

2. Bertin, J. 2013. Sémiologie graphique : Les diagrammes, les réseaux, les cartes. Paris: Editions de l'Ecole des Hautes Etudes en Sciences Sociales (First Edition 1967).

3. Bihl, L. Le Traître, Decryptimage, Available at https://www.decryptimages.net/analyses-detail/dessi ns-de-presse/582-oswald-heidbrinck-le-traitre. Accessed 5 Nov 2018.

4. Birnbaum, P. 1994. L'affaire Dreyfus: La république en péril. Paris: Gallimard.

5. Bourrelier, P.-H. (2007). La Revue Blanche: Une génération dans l'engagement 1890-1905. Paris: Fayard (pages 576-601 on le Cri de Paris).

6. Dixmier, M. 1980. Jossot, Cahier de l'art mineur, no 23. Saint-Denis: Le vent du ch'min et Limage.

7. Durand, J. 1970. Rhétorique et image publicitaire. Communications 15: 70-95. Available at https:// www.persee.fr/doc/comm_0588-8018_1970_num_15_1_1215. Accessed 5 Sept 2018.

8. Eco, U. 1985. Lector in fabula ou La coopération interprétative dans les textes narratifs. Paris: Grasset.

9. Encyclopédie Universalis. Assiette au beurre. Available at https://www.universalis.fr/encycloped ie/l-assiette-au-beurre-1/. Accessed 5 Sept 2018.

10. Grand-Carteret, J. 1898. L'Affaire Dreyfus et l'image. Paris: Flammarion.

11. Jakobson, R. 1936. Essai de linguistique générale, 218. Paris: Minuit.

12. Jakobson, R. 1957. Shifters, verbal categories, and the Russian verb. Selected Writings, Vol II, Word and Language, The Hague: Mouton, 1971.

13. Joly, M. 2011. L'image et les signes: approche sémiologique de l'image fixe. Paris: Armand Colin.

14. Joly, M. 2015. Introduction à l'analyse de l'image, 3rd ed. Paris: Armand Colin.

15. Joly, M. 2005. L'image et son interprétation. Paris: Armand Colin. 
16. Kharbouch, A. 2014. La séméiotique de Peirce et la sémiologie de Saussure : une antithèse ? Actes sémiotiques, n.117. Available at http://epublications.unilim.fr/revues/as/5218. Accessed 11 July 2018.

17. Kostenevich, A.G. 2012. The Nabis. New York: Parkstone International.

18. L'Assiette au beurre. Available at https://gallica.bnf.fr/ark:/12148/bpt6k1047752k/f2.item. Accessed 2 Nov 2018.

19. Le Petit journal, 13 January 1895. Available at http://web.nli.org.il/sites/NLI/English/collections/ PersonalWebs/Dreyfus/Storyline/Pages/default.aspx. Accessed 17 Oct 2018.

20. Lotman, A. 1973. La structure du texte artistique. Paris: NRF.

21. Moles, A. 1972. Théorie de l'information et perception esthétique. Paris: Denoël.

22. Mollier, J.-Y. 1998. Zola et la rue. Les Cahiers naturalistes ${ }^{\circ} 73,80-88$.

23. Oriol, P., and S. Faure. 2002. Les anarchistes de l'affaire Dreyfus. Paris: Editions CNT-Région parisienne.

24. Osborn, Al. 1959. L'imagination constructive. Paris: Dunod.

25. Oxford Living Dictionaries, https://en.oxforddictionaries.com/definition/truth. Accessed 11 Nov 2018.

26. Pages, A. 1996. Émile Zola, un intellectuel dans l'affaire Dreyfus. Paris: Séguier.

27. Pages, A. 2003. La rhétorique de J'accuse, in Spectacles de la parole, Millot, H. and SaminadayarPerrin, C. Saint-Etienne: Éditions des Cahiers intempestifs, coll. «Lieux littéraires 5», 135-146.

28. Preiss. N. 2002. De POUFF à PSCHITT ! De la blague et de la caricature politique sous la Monarchie de Juillet. Romantisme ${ }^{\circ} 116,5-17$.

29. Roque, G. 1970. A propos du Traité du signe visuel : une remarque et deux questions, Actes Sémiotiques, Available at http://epublications.unilim.fr/revues/as/3128.

30. Saint-Martin, F. 1990. Semiotics of visual language. Bloomington: Indiana University Press.

31. Tillier, B. 1999. Virulences verbales et graphiques au cœur de l'affaire Dreyfus. Ridiculosa $n^{\circ} 6$. Available at https://eiris.eu/index.php?option=com_content\&view=article\&id=348:virulences -verbales-et-graphiques-au-cur-de-laffaire-dreyfus. Accessed 27 Nov 2018.

32. Tillier, B. 1998. La caricature antisémite pendant l'affaire Dreyfus: le stéréotype du Juif errant. Persée. Available at https://www.persee.fr/doc/homig_1142-852x_1998_num_1216_1_3250. Accessed 8 Sept 2018.

33. Viltard, H. Elle était trop nue, Available at http://gustave.jossot.free.fr/tropnue.html. Accessed 2 Dec 2018.

34. Winock, M. 1998. L'affaire Dreyfus. Paris: Seuil, Points Histoire.

35. Zola, E. 1898, J'accuse, L'Aurore, Available at https://www.nouvelobs.com/societe/20060 712.OBS4922/j-accuse-par-emile-zola.html in French, and for an English translation: https:// en.wikisource.org/wiki/Translation:J\%27Accuse\%2E\%2E\%2E\%21. Accessed 29 Nov 2018.

Publisher's Note Springer Nature remains neutral with regard to jurisdictional claims in published maps and institutional affiliations. 